\title{
PENYELESAIAN MASALAH KONTROL OPTIMUM SEBAGAI MASALAH SYARAT BATAS PERSAMAAN DIFERENSIAL BIASA DALAM SCILAB
}

\author{
Agah D. Garnadi, Effendi Syahril
}

\begin{abstract}
Abstrak
Diuraikan penggunaan rutin bvode di lingkungan SCILAB untuk menyelesaikan masalah syarat batas sistem persamaan diferensial biasa untuk menyelesaikan masalah Kontrol Optimum. Tujuan tulisan ini bersifat pedagogis dengan tujuan pengguna dapat mempergunakan solver bvode untuk memecahkan secara numeric MKO setelah membaca uraian penggunaan pemecahan masalah syarat batas. Penggunaan rutin digambarkan dengan tiga contoh masalah syarat batas, salah satu diantaranya merupakan MSB KO.
\end{abstract}

\section{PENDAHULUAN}

Persamaan Diferensial Biasa (PDB) sering muncul sebagai model permasalahan dalam berbagai bidang ilmu pengetahuan. Pencarian solusi PDB diperlukan untuk memperoleh interpretasi dari model permasalahan semula. Solusi analitik dari suatu PDB tidak selalu mudah diperoleh, sehingga metode numeric diperlukan untuk mendapatkan solusi permasalahan.

Ada kalanya solusi yang sangat spesifik ingin didapatkan dari suatu sistem PDB dengan cara menentukan nilai-nilai awal pada lebih dari satu titik $x$. Permasalahan seperti ini dikenal dengan nama Masalah Syarat Batas (MSB), yang dapat dinyatakan oleh :

$$
\begin{aligned}
y^{n} & =f\left(x, y, y^{\prime}, y^{\prime \prime}, \ldots, y^{n-1}\right) \\
y\left(a_{1}\right) & =b_{1} \\
y\left(a_{2}\right) & =b_{2}
\end{aligned}
$$

Dalam lingkunagn Scilab, sebuah rutin untuk menyelesaikan MSB berdasarkan metode kolokasi disediakan, rutin ini bernama bvode. Metode kolokasi juga digunakan dalam lingkungan MATLAB untuk rutin bvp4c yang disediakannya.

Tulisan ini merupakan sebuah tutorial yang memberikan penuntun bagaimana memformulasikan masalah (menyusun perintah), untuk mendapatkan

\footnotetext{
${ }^{1}$ Departemen Matematika, Fakultas Ilmu Pengetahuan Alam, Jalan Meranti Kampus IPB Dramaga Bogor, 16680 .
} 
solusi numerik, dan menggambarkan solusi secara grafis dari MSB yang berasal dari Masalah Kontrol Optimum (MKO) dengan menggunakan rutin bvode. Tulisan ini juga merupakan studi pendahuluan numerik atas ketersediaan lingkungan pemecah masalah numerik (numerical problem solving environment $\{\mathrm{PSE}\})$ yang bersifat open-source sebagai alternatif dari PSE komersial populer MATLAB yang menawarkan rutin bvp4c untuk memecahkan MSB.

Tujuan tulisan ini bersifat pedagogis yang menguraikan secara sederhana bagaimana MKO didapatkan solusinya dengan menyelesaikan secara numerik MSB sebuah PDB. Dengan demikian, seorang pemula dapat mempergunakan bvode untuk menyelesaikan MSB yang dihadapinya tanpa kesulitan.Selain itu, contoh yang diberikan muncul dari masalah perkuliahan yang biasanya ditemui di tahun ketiga atau keempat di perguruan tinggi.Selain itu, tulisan ini bertujuan untuk menyediakan dokumentasi tertulis berbahasa Indonesia.Tujuan lainnya ialah memberikan teladan penggunaan Open Source dilingkungan komputasi matematika di Indonesia, yang secara tidak langsung memberi dukungan pada proyek nasional IGOS (Indonesia Goes Open Source).

Tulisan ini disusun dengan urutan sebagai berikut.Pertama diuraikan formulasi masalah control optimum, yang dilanjutkan dengan deskripsi dari bvode. Kemudian diperlihatkan penggunaannya untuk sebuah contoh MKO sebagai masalah syarat batas yang diselesaikan menggunakan bvode. Untuk kepentingan pedagogis, diberikan dua contoh MSB yang diselesaikan menggunakan bvode dalam lingkungan Scilab. Kemudian diakhiri oleh kesimpulan serta kemungkinan pekerjaan lanjutan.

\section{FORMULASI MASALAH KONTROL OPTIMUM SEBAGAI MASALAH SYARAT BATAS}

Disini kita inginkan untuk menentukan input $\mathbf{u}(t)$ untuk meminimumkan fungsional scalar:

$$
\mathcal{J}=\phi\left(\mathrm{x}\left(t_{f}\right)\right)+\int_{0}^{t_{f}} L(\mathrm{x}, \mathbf{u}, t) d t
$$

dengan diberikana dinamika tak-linear berbentuk:

$$
\dot{\mathrm{x}}=\mathbf{f}(\mathbf{x}, \mathbf{u}, t), \quad \mathrm{x}(t=0)=\mathrm{x}_{0}
$$
berikut

Solutsi persamaan (1) diperoleh melalui Kalkulus Variasi berupa MSB 
JMA, VOL. yy, NO.1, JULY 2018, 1-xx

$$
\begin{aligned}
& \dot{\mathbf{x}}=\mathbf{f}(\mathbf{x}, \mathbf{u}, t), \quad \mathrm{x}\left(t_{0}\right)=\mathrm{x}_{0} \\
& \dot{\lambda}=-\frac{\partial H}{\partial \mathrm{x}}, \quad \lambda\left(t_{f}\right)=\left.\frac{\partial \phi}{\partial \mathrm{x}}\right|_{t_{f}}
\end{aligned}
$$

Dengan $\lambda$ merupakan varibel co-state, dengan Hamiltonian $H \stackrel{\text { def }}{=} L+\lambda^{T} \mathbf{f}$ Serta input kontrol yang merupakan solusi dari:

$$
\frac{\partial L}{\partial \mathbf{u}}+\lambda^{T} \frac{\partial \mathbf{f}}{\partial \mathbf{u}}=0
$$

Persamaan (5) tidak trivial untuk menyelesaikannya, karena harus menyelesaikan MSB (3) dan (4) dengan kendala yang bersifat aljabar.

\section{DESKRIPSI bvode}

Rutin bvode yang tersedia dalam PSE Scilab, merupakan perangkat simulasi untuk menyelesaikan MSB.Rutin bvode pada dasarnya mempergunakan pustaka COLNEW yang merupakan perbaikan dari rutin program COLSYS ([1], [2]) yang ditulis mempergunakan FORTRAN dan berlandaskan metode kolokasi.Tidak seperti solver PDB pada umumnya, bvode tidak mengharuskan pengguna mengubah persamaan diferensial orde tinggi menjadi sistem persamaan diferensial orde satu. Selain itu, dimungkinkan diberikannya sejumlah syarat di sejumlah titik

Bentuk MSB yang diasumsikan oleh bvode ialah:

$$
\begin{gathered}
\frac{d^{m_{\mathrm{i}}} y_{i}}{d x^{m_{i}}}=f_{i}\left(x, y(x), \frac{d y}{d x}, \ldots, \frac{d^{m_{\mathrm{i}}-1} y_{i}}{d x^{m_{i}}-1}\right), \quad 1 \leq i \leq n_{c}, \\
g_{j}\left(\zeta_{j} y\left(\zeta_{j}\right), \ldots, \frac{d^{m_{*}} y}{d x^{m_{*}}}\left(\zeta_{j}\right)\right)=0, \quad j=1, .
\end{gathered}
$$

Dengan merupakan posisi dimana syarat batas berlaju dan $\quad a_{L} \leq \zeta_{j}$. Agar notasi tidak menyulitkan, tuliskan

$$
\begin{aligned}
& m_{*}=m_{1}+m_{2}+\cdots+m_{n_{c^{3}}} \\
& z(y)=\left[y, \frac{d y}{d x}, \ldots, \frac{d^{m_{*} y}}{d x^{m_{*}}}\right] .
\end{aligned}
$$




\section{A.D. GARNADI, E. SYAHRIL}

Dengan demikian, bentuk umum MSB yang diasumsikan oleh bvode ialah

$$
\begin{gathered}
\frac{d^{m_{i}} y_{i}}{d x^{m_{i}}}=f_{i}(x, z(y(x))), \quad 1 \leq i \leq n_{c}, \quad a_{L} \leq \zeta_{j} \leq a_{R}, \\
g_{j}\left(\zeta_{j}, z\left(y\left(\zeta_{j}\right)\right)\right)=0, \quad j=1, .
\end{gathered}
$$

Rutin bvode memiliki kemampuan untuk menyelesaikan MSB yang linear maupun non-linear. Karena itu rutin ini mengharuskan pengguna menyusun sendiri matriks Jacobian dari PDB yang hendak diselesaikan, maka untuk beberapa masalah, tingkat kerumitan yang paling besar akan terasa pada penyusunan matriks Jacobian ini.

Seperti halnya fungsi lain pada SCILAB, rutin bvode memiliki tata cara pemanggilan sebagai berikut ini

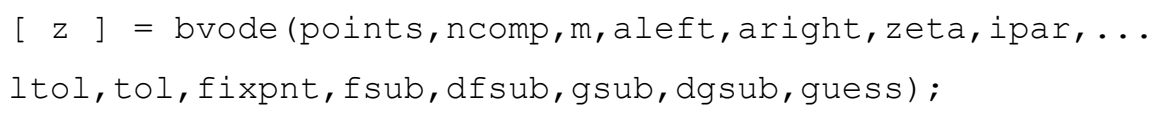

dengan z merupakan vektor baris yang berisi solusi numerik dari MSB yang ingin diselesaikan. Komponen $z(i,:)$ merepresentasikan turunan ke-( $i-1)$ dari solusi pada selang domain. Sebagai contoh, $z(1,:)$ menyatakan $y, z(2,:)$ menyatakan $y^{\prime}$, dan seterusnya hingga $z\left(\mathrm{~m}^{*},:\right)$ menyatakan $y^{\left(\mathrm{m}^{*}-1\right)}$.

Lima argumen terakhir yang diperlukan bvodeberbentuk fungsi yang harus didefinisikan sendiri oleh pengguna, sedangkan argumen lainnya merupakan informasi yang diperlukan bvode untuk dapat mencari solusi numerik berkaitan dengan MSB yang ingin diselesaikan.Berikut adalah penjelasan kegunaan masing-

\begin{tabular}{|c|c|c|}
\hline & & \\
\hline bints & & $\begin{array}{l}\text { ang menyimpan titik di selang domain dimana MSB akan dicari } \\
\text { ya. }\end{array}$ \\
\hline comp & & nlah persamaan diferensial. Syaratnya haruslah ncomp $\leq 20$. \\
\hline $\mathrm{M}_{1}$ & & $\begin{array}{l}\text { ktor dengan panjang ncomp, yang isinya } m(j) \text { berupa orde dari } \\
\text { samaan diferensial ke-j. Orde dari persamaan diferensial harus } \\
\text { yaratkanm }(j) \leq 4 \text {. }\end{array}$ \\
\hline l] ft & & ri dari selang domain dimana $y$ didefinisikan. \\
\hline & & nan dari selang domain dimana $y$ didefinisikan. \\
\hline & & $\begin{array}{l}\text { zeta }(j) \text { berisi titik syarat (batas) tambahan ke-j. Isi harus diurutkan } \\
\text { ingga zeta }(j) \leq \text { zeta }(j+1) \text {. Semua titik syarat tambahan (batas) } \\
\text { us pada titik mesh di semua mesh yang digunakan. Khususnya, titik } \\
\text { ebut harus merupakan bagian dari mesh awal. Perhatikan pula uraian } \\
\text { ih rinci mengenai parameter ipar (11) dan fixpnt di bawah ini. }\end{array}$ \\
\hline ipar & & $\begin{array}{l}\text { Array berentri bilangan bulat dengan ukuran sedikitnya } 11 \text {. Daftar } \\
\text { parameter dari ipar akan diuraikan kemudian. }\end{array}$ \\
\hline ltol & & Array dengan panjang yang ditentukan \\
\hline & & $\begin{array}{l}\text { ltol }(j)=1 \text { menentukan toleransi ke- } j \text { di tol mengendalikan error di } \\
\text { komponen ke-l dari } \mathrm{z}(u) \text { Juga dipersyaratkan bahwa }\end{array}$ \\
\hline
\end{tabular}
masing parameter yang digunakan oleh bvode. 
JMA, VOL. yy, NO.1, JULY 2018, 1-xx

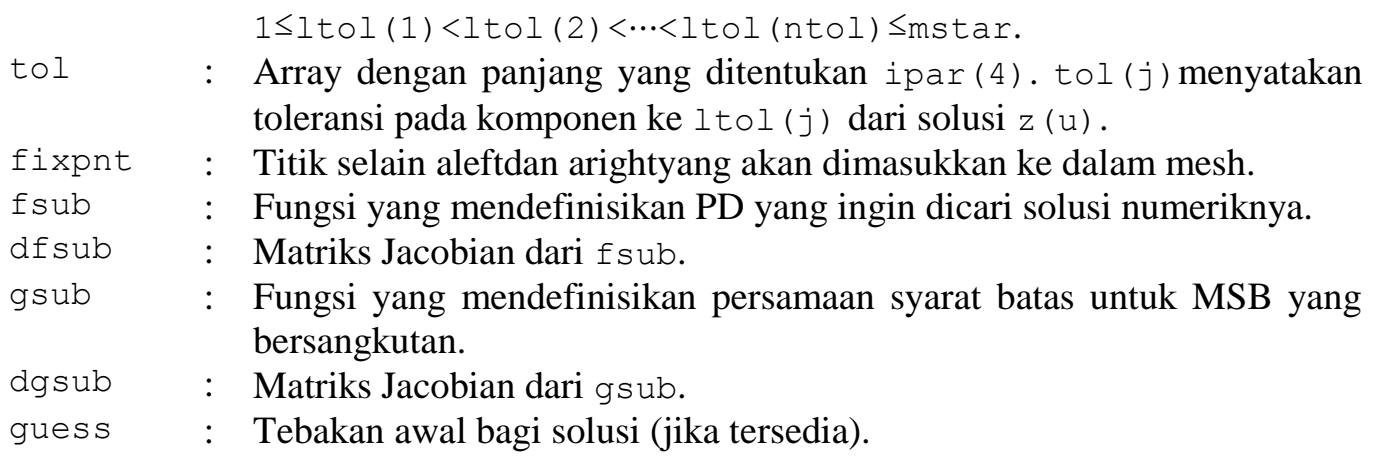

Dari kelimabelas parameter di atas, argumen ipar adalah argumen yang paling panjang.Argumen ini memiliki 11 komponen yang secara keseluruhan memberi kesempatan pengguna untuk mengatur setting pada metode numerik yang digunakan bvode.Sebagian komponen dari parameter ipar berhubungan langsung dengan beberapa argumen bvode pada daftar parameter di atas. Sebagian besar dari komponen-komponen tersebut memiliki nilai default nol. Karena jumlah komponennya yang terbilang cukup banyak, ada baiknya jika dibuat variabel berdimensi $1 \times 11$ yang berisi nilai nol (default) sebelum mengisi komponen-komponen yang tidak bernilai default, yaitu

ipar $=\operatorname{zeros}(1,11) ;$.

Isikan masing-masing komponen parameter ipar berdasarkan keterangan yang didaftarkan di bawah ini:

ipar(1) : $\quad=0$ jika MSB linear dan = 1 jika MSB non-linear.

ipar(2) : Banyaknya titik kolokasi per subinterval $(=k)$ dimana orde maksimum PD $\leq k \leq 7$. Jika ipar (2)=0maka secara default $k=\max (\max$ $m(i)+1,5-\max m(i))$.

ipar(3) : Banyaknya subinterval pada mesh awal $(=n)$. Jika ipar(3) $=0$ maka secara default $n=5$.

ipar(4) : Banyaknya komponen solusi beserta turunannya yang diberi toleransi (=ntol), dengan aturan $0 \leq n t o l \leq m^{*}$.

ipar(5) : Nilai yang menentukan banyaknya subinterval maksimum (nmax) pada selang domain. Pilihlah ipar(5) berdasarkan rumus berikut: ipar(5) Zipar(5).nsizef di mana nsizef = $4+3 m *+(5+k d) \cdot k d m+(2 m *-n r e c) \cdot 2 m *$ dengan nrec adalah banyaknya syarat batas pada ujung kanan selang domain ipar(5) diperuntukkan evaluasi pada titik-titik selang real.

ipar(6) : Nilai yang menentukan banyaknya subinterval maksimum nmax pada selang domain. Pilihlah ipar(6) berdasarkan rumus berikut:

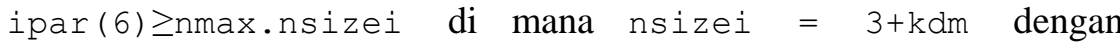
$\mathrm{kdm}=\mathrm{kd}+\mathrm{m}^{*} ; \mathrm{kd}=\mathrm{k} \cdot \mathrm{ncomp} ;$ ipar (6) diperuntukkan evaluasi pada titik-titik integer.

ipar(7) : Kontrol output berikan nilai berikut: $=-1$ untuk printout diagnostik penuh $=0$ untuk printout sederhana. $=1$ tanpa printout.

ipar (8) : =0 untuk mesh awal seragam. 


\title{
A.D. GARNADI, E. SYAHRIL
}

\begin{abstract}
ipar (9) : = 0 jika tidak tersedia tebakan awal bagi solusi. = 1 jika tebakan awal tersedia pada fungsiguess.

ipar(10) = 0 jika masalah bersifat reguler. $=1$ jika iterasi nonlinear tidak bergantung pada kekonvergenan dari iterasi sebelumnya (hanya digunakan jika ipar $(1)=1$ ). = 2 jika proses ingin dihentikan setelah (a)terjadi dua kali nonkonvergen berturut-turut, atau (b)pendekatan galat didapatkan untuk pertama kalinya.

ipar(11) : Banyaknya titik selain ujung-ujung selang domain yang akan dimasukkan ke dalam mesh (dimensi dari argumen fixpnt).
\end{abstract}

\section{CONTOH}

Untuk kepentingan pedagogis, dibahas tiga contoh bagaimana menyelesaikan MSB dengan mempergunakan bvode, dengan contoh terakhir yang berupa contoh MKO sebagai MSB. Selain itu, ditunjukkan pula bagaimana cara menggambar masing-masing komponen solusi numerik yang didapat dari bvode.

Contoh 1. Dalam contoh ini diberikan ilustrasi bagaimana mencari solusi numerik dari MSB yang melibatkan parameter yang tidak diketahui. Permasalahannya ialah menghitung nilai eigen dari persamaan Mathieu berikut ini,

$y^{\prime \prime}+(\lambda-2 q \cos (2 x)) y=0$

pada selang , dengan syarat batas $\quad y^{\prime}\left(0, \quad y^{\prime}(\pi\right.$ untuk . Solusi dinormalisasi dengan cara menetapkan solusi memenuhi $\quad y(0$. Permasalahan sesungguhnya ialah mencari nilai yang memenuhi syarat batas $\quad y^{\prime}(\pi$. Nilai tebakan awal bagi menjadi keharusan dalam menyelesaikan masalah ini.MSB di atas diimplementasikan dalam SCILAB sebagai berikut ini.Persamaan diferensialnya didefinisikan dengan skrip berikut.

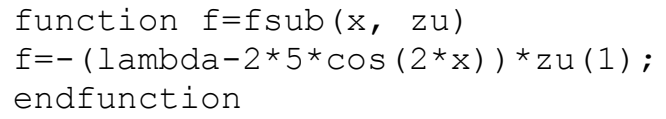

Untuk persamaan di atas, diperlukan matriks Jacobian yang ditulis dengan skrip seperti berikut ini.

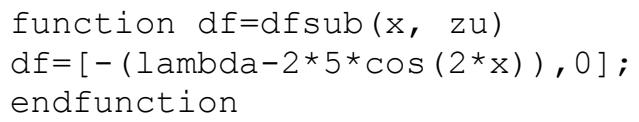

Sementara syarat batasnya diberikan oleh:

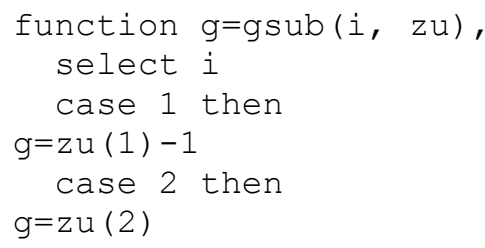




\section{JMA, VOL. yy, NO.1, JULY 2018, 1-xx}

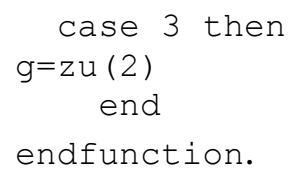

Untuk syarat batas tersebut di atas, diperlukan matriks Jacobian, yaitu

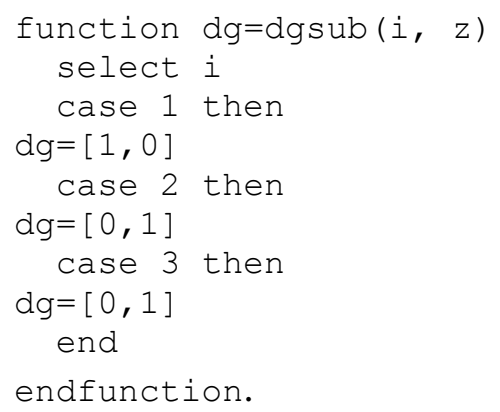

Berikut sejumlah parameter yang diperlukan, yaitu

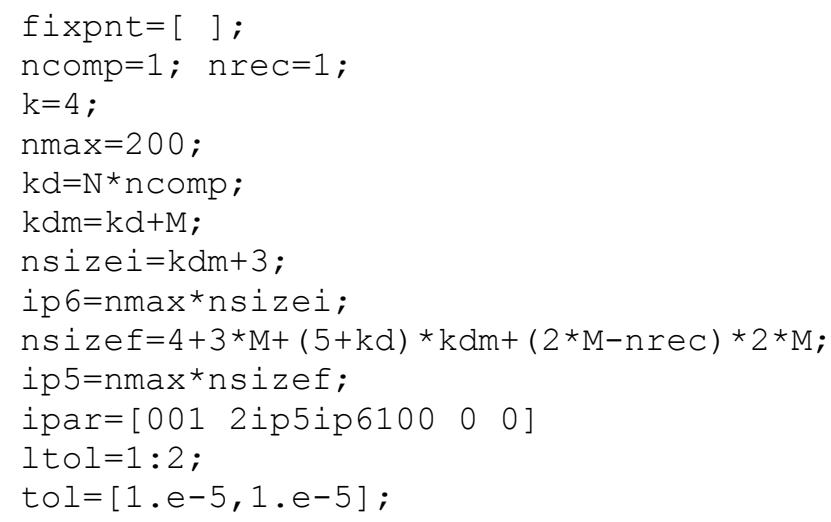

Karena tebakan awal bagi solusi $y$ tidak tersedia maka fungsi guess didefinisikan seperti di bawah ini.

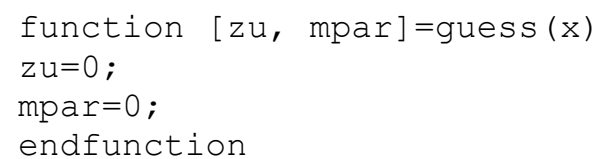

Jika tebakan awal bagi nilai eigen dipilih $=15$, maka untuk menyelesaikan MSB pada persamaan (7) sekaligus mendapatkan nilai pendekatan untuk dapat dilakukan dengan menambahkan loop seperti pada listing berikut,

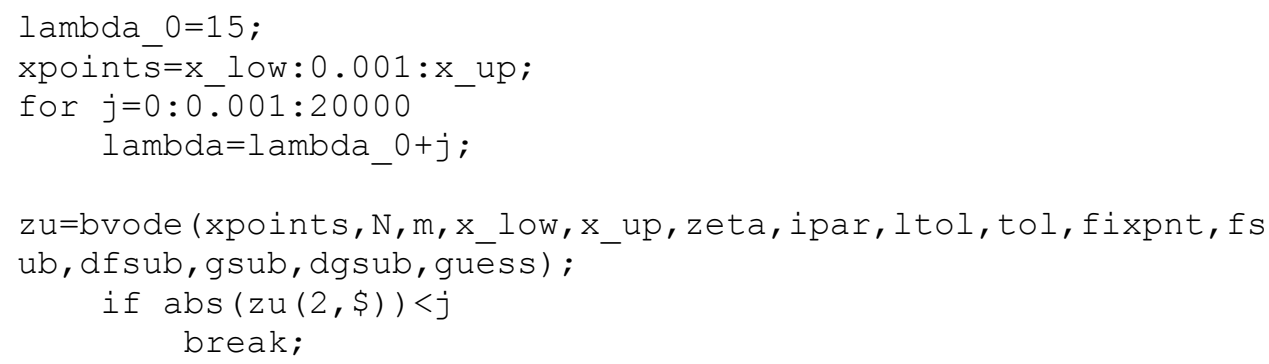




$$
\text { end end; }
$$

Untuk melihat gambar grafik solusi numerik untuk $y(x)$ yang dihasilkan bvode dan untuk mengetahui nilai yang didapat dari loop di atas, perintah berikut dengan cepat akan menampilkan keduanya:

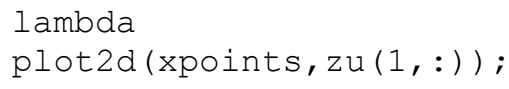

Dari hasil perhitungan yang dilakukan oleh bvode beserta loop di atas, didapat nilai pendekatan $=16.058$ dan gambar grafik solusi $y(x)$ seperti yang terlihat pada Gambar 1. Perhitungan di atas mempergunakan mesh dengan lebar kisi $\Delta x=0.001$ yang seragam untuk selang $[0, \pi]$.

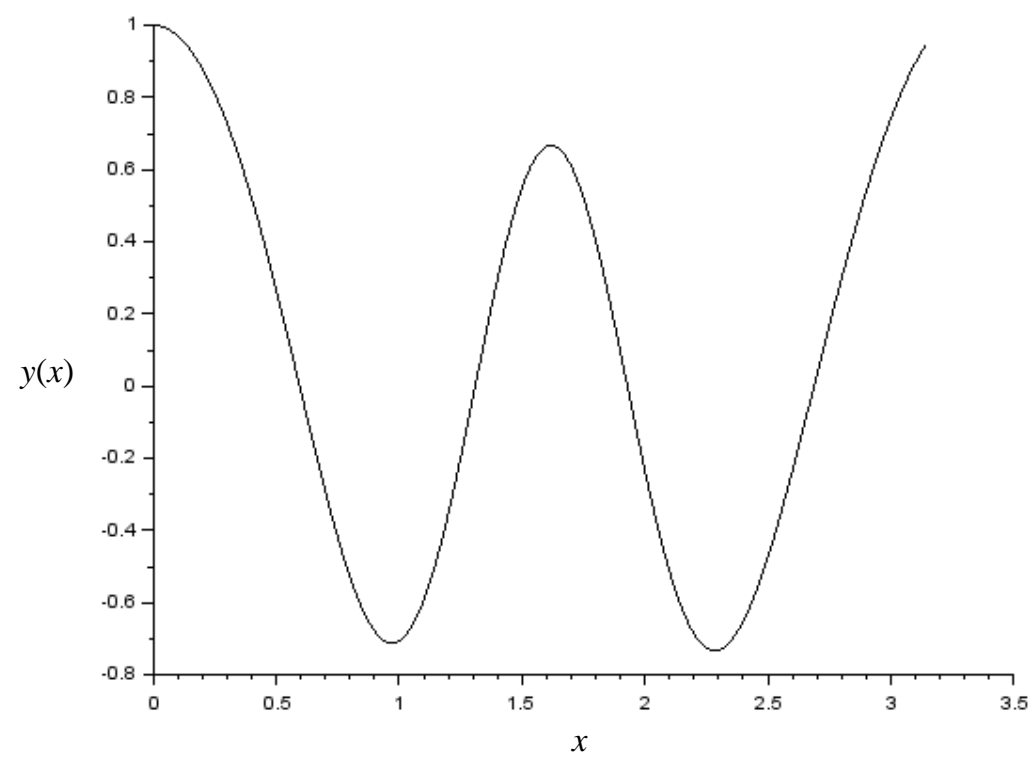

Gambar 1 Fungsi eigen dari persamaan Mathieu terkait dengan nilai eigen yang digunakan dalam artikel

Contoh 2. Pada contoh berikut diberikan sebuah MSB yang berasal dari formula kredibilitas yang memungkinkan aktuaris untuk menyeimbangkan dua hal, yaitu keakuratan dan kelinearan [9]. Berikut merupakan MSB untuk kasus di mana sebaran marginal ( ) dari besarnya klaim( ) ialah tak nol pada suatu interval terbatas , lihat Young [10].

$$
\begin{aligned}
& \frac{h}{f(x)}\left[f(x) d^{\prime \prime}(x)\right]^{\prime \prime}+d(x)=\mu(x), \\
& \text { dengan } \\
& d^{\prime \prime}(a)=d^{\prime \prime}(b)=d^{n \prime}(a)=d^{n \prime}(b)=0 .
\end{aligned}
$$


$\mu(x)=\frac{2}{(x+2) \ln 1.5}-2+\frac{2}{(x+2)} \int_{1}^{0.5 x+1} \frac{3-2 \theta}{\ln 1.5-\ln \theta} d \theta . \quad h=0$, dan Misalkan pula

$v(x)=\int_{1}^{0.5 x+1} \frac{3-2 \theta}{\ln 1.5-\ln \theta} d \theta$,

sehingga

$$
v^{\prime}(x)=\frac{1-x}{2[\ln 1.5-\ln (0.5 x+1)]} .
$$

Dengan demikian, persamaan (10) menjadi

$$
\begin{aligned}
0.0025 d^{\prime \prime \prime}(x)+d(x) & =\frac{2}{(x+2) \ln 1.5}-2+\frac{2}{(x+2)} v(x) \\
d^{\prime \prime \prime}(x) & =\frac{1}{0.0025}\left[\frac{2}{(x+2) \ln 1.5}-2+\frac{2}{(x+2)} v(x)-d(x)\right] .
\end{aligned}
$$

Jadi, MSB untuk kasus tersebut ialah

$$
\begin{aligned}
& v^{\prime}(x)=\frac{1-x}{2[\ln 1.5-\ln (0.5 x+1)]^{\prime \prime}} \\
& d^{\prime \prime \prime}(x)=\frac{1}{0.0025}\left[\frac{2}{(x+2) \ln 1.5}-2+\frac{2}{(x+2)} v(x)-d(x)\right],
\end{aligned}
$$

dengan

$v(0)=d^{\prime \prime}(0)=d^{\prime \prime}(1)=d^{\prime \prime \prime}(0)=d^{\prime \prime \prime}(1)=0$.

MSB di atas diimplementasikan dalam SCILAB sebagai berikut.Persamaan diferensialnya didefinisikan dengan skrip berikut.

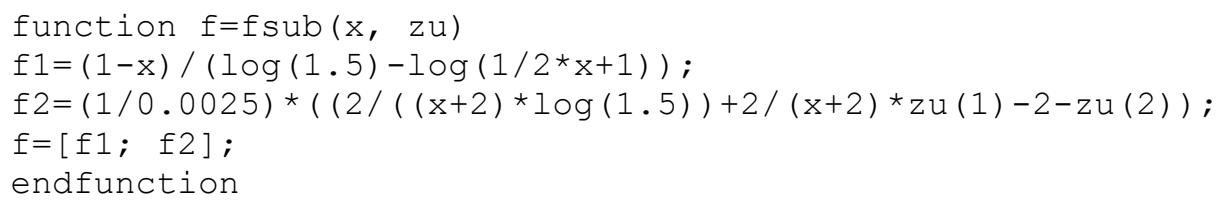

Untuk persamaan di atas, diperlukan matriks Jacobian yang ditulis dengan skrip seperti berikut ini.

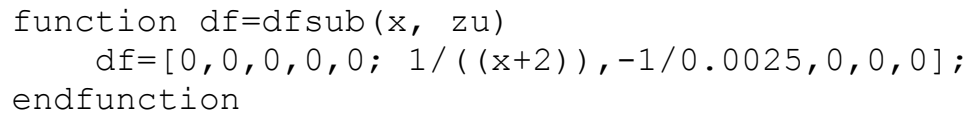

Sementara syarat batasnya diberikan oleh:

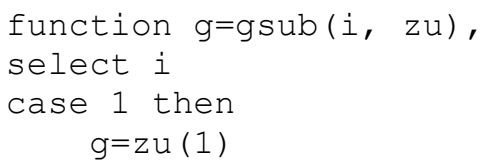


A.D. GARNADI, E. SYAHRIL

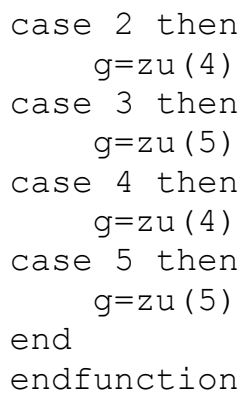

Untuk syarat batas tersebut, diperlukan matriks Jacobian, yaitu

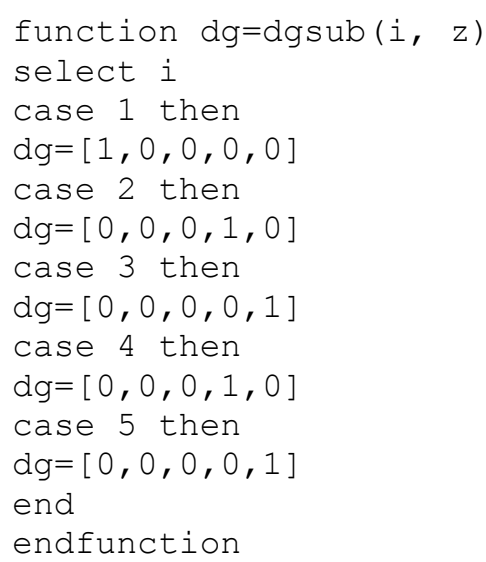

MSB di atas, diselesaikan di atas selang [0,1] dengan lebar kisi $\Delta t=0.01$ yang seragam, berikut sejumlah parameter yang diperlukan, yaitu

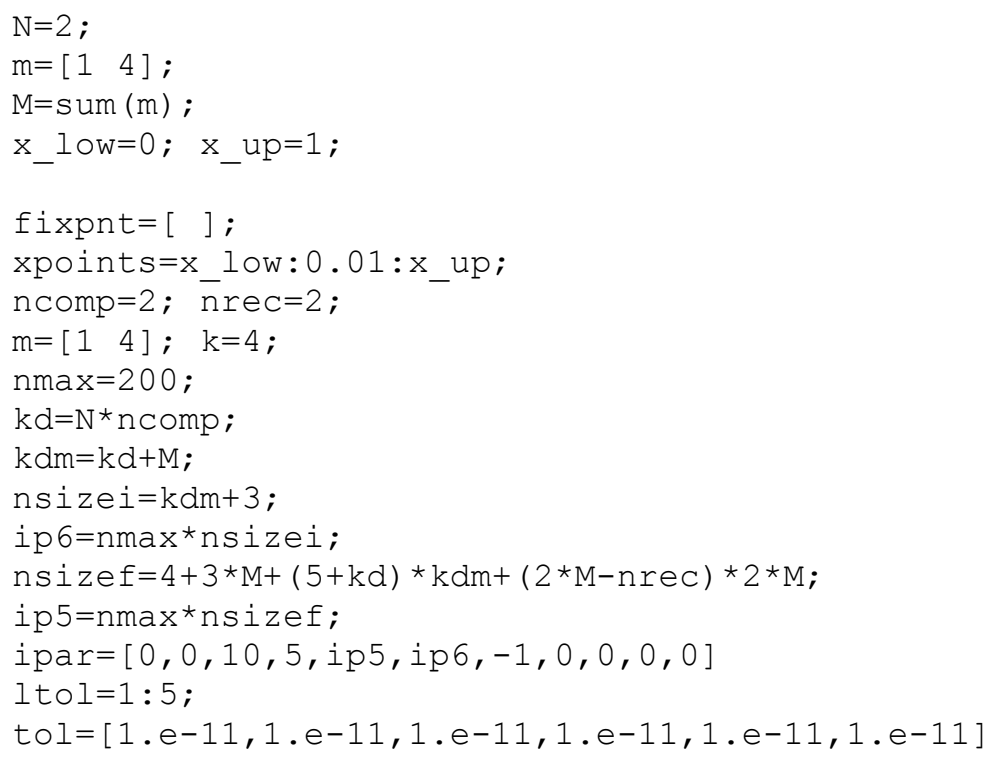

dan kita berikan fungsi tebakan awal, yaitu

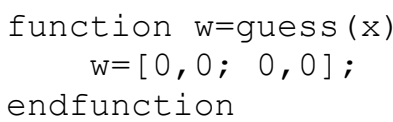


Kemudian untuk memperoleh solusi numerik MSB, diberikan dalam skrip SCILAB berikut

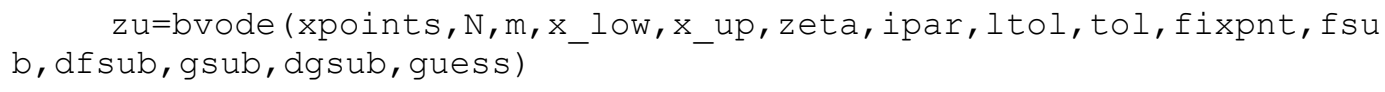

Solusi numerik yang diperoleh, ditampilkan oleh Scilab dengan memberikan skrip berikut ini

plot (xpoints, zu (1, :)) .

Tampilan grafisnya diperlihatkan pada Gambar 2.

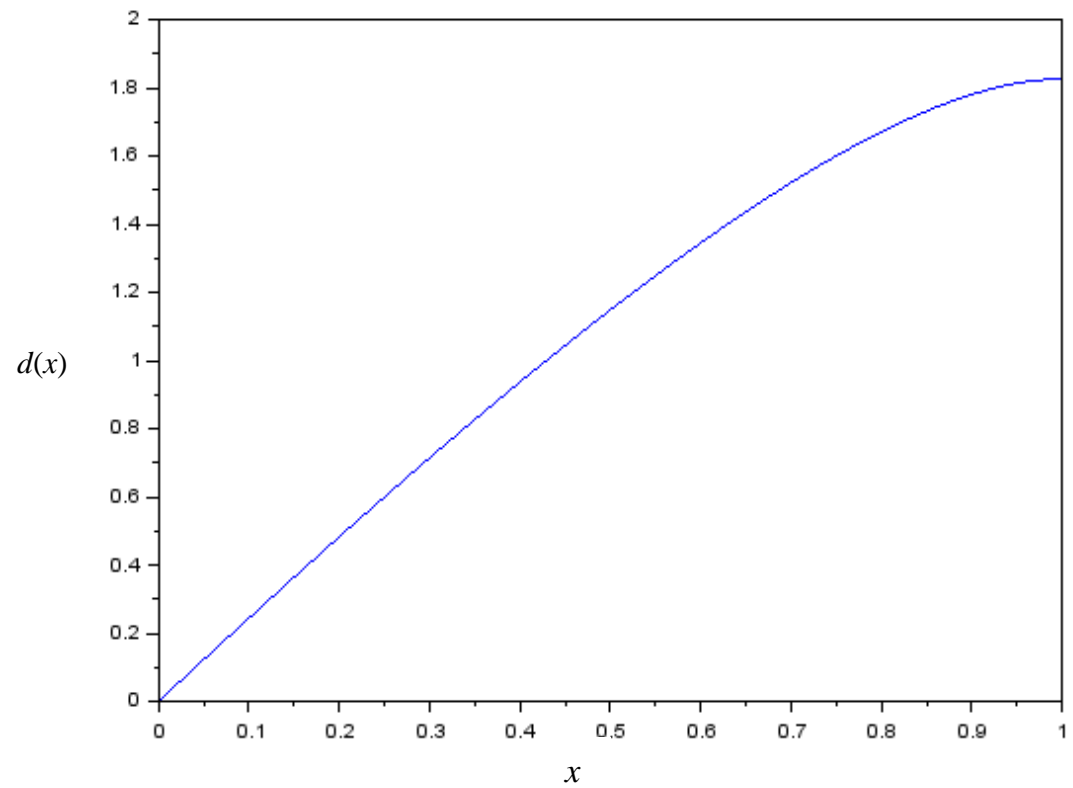

Gambar 2. Solusi optimum (d) dengan $h=0.0025$.

Contoh 3. Pada contoh berikut diberikan sebuah MSB yang berasal dari Kontrol Optimum. Biasanya, syarat cukup untuk kontrol optimum berupa MSB, yang biasanya lebih mudah menyelesaikannya untuk banyak masalah sederhana.

$y^{\prime}=y^{2}+v$

Perhatikan masalah sistem terkontrol

dan kita inginkan kontrol $v$ mengendalikan lintasan dari 2 pada saat $t=0 \mathrm{ke}-1$ pada saat $t=10$. Dengan demikian, kita inginkan $v$ meminimumkan ongkos kuadratik berikut

$$
l(y, v)=\int_{0}^{10}\left(y^{2}+10 v^{2}\right) d t .
$$

Fungsi ongkos ini menyebabkan variabel keadaan $y$ dan variabel kontrol $v$ terpenalisasi, sehingga menyebabkan variabel keadaan dan kontrol menjadi kecil.

Syarat cukup dapat diperoleh dengan mendefinisikan fungsi Hamiltonian 


$$
H=\left(y^{2}+10 v^{2}\right)+\lambda\left(y^{2}+v\right)
$$

dan kita tuliskan masalah syarat batas persamaan diferensial aljabar

$y^{\prime}=\frac{\partial H}{\partial \lambda^{3}}$

$\lambda^{*}=\frac{\partial H}{\partial y^{\prime}}$

$0=\frac{\partial H}{\partial v^{\prime}}$

$y(0)=2, y(10)=1$,

Bila $v$ dieliminasi, akan diperoleh MSB

$y^{\prime}=y^{2}+v_{x}$

$\lambda^{*}=-2 y-2 \lambda y$,

$0=20 v+\lambda$,

$y(0)=2, y(10)=1$,

MSB di atas diimplementasikan dalam SCILAB sebagai berikut ini.Persamaan diferensialnya didefinisikan dengan skrip berikut.

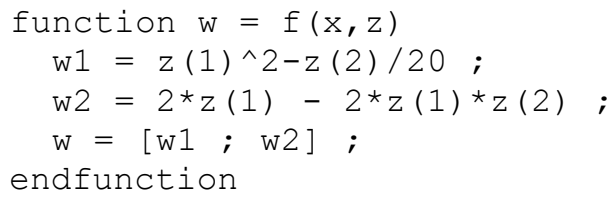

Untuk persamaan di atas, diperlukan matriks Jacobian yang ditulis dengan skrip seperti berikut ini.

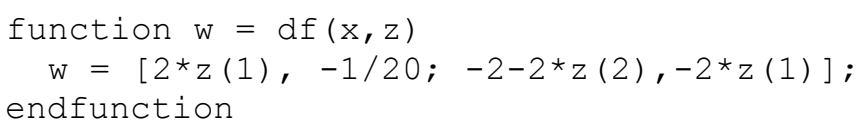

Sementara syarat batasnya diberikan oleh:

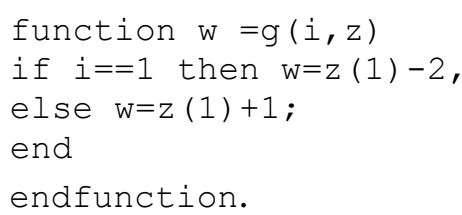

Untuk syarat batas tersebut di atas, diperlukan matriks Jacobian, yaitu

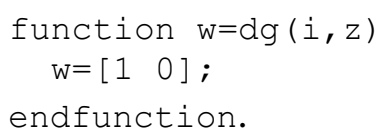

MSB di atas, diselesaikan di atas selang $[0,10]$ dengan lebar kisi $\Delta t=0.1$ yang seragam, berikut sejumlah parameter yang diperlukan, yaitu 


\section{JMA, VOL. yy, NO.1, JULY 2018, 1-xx}

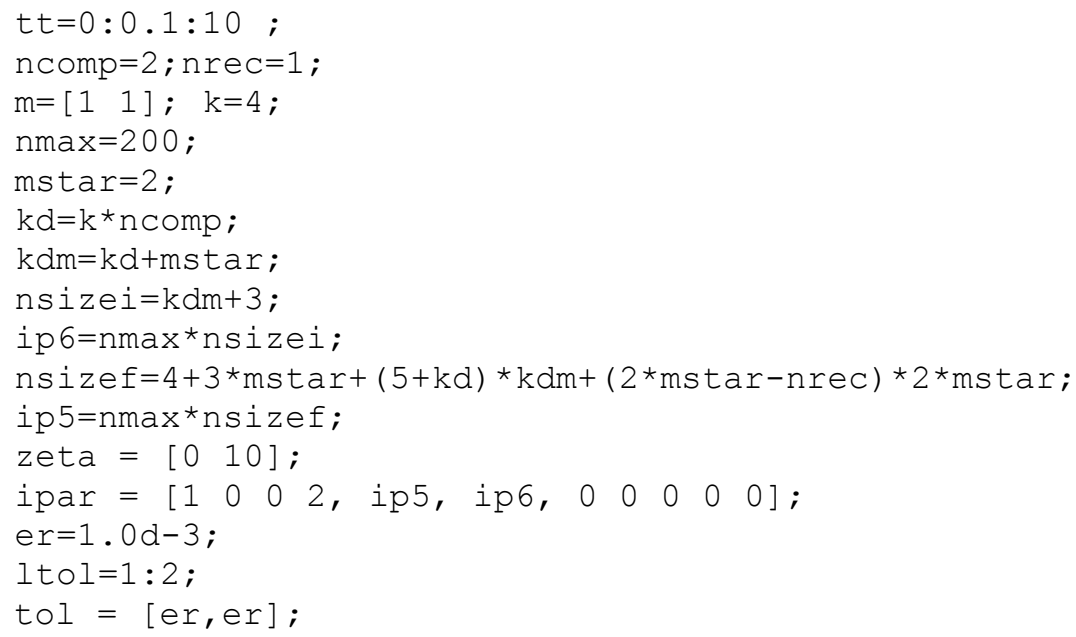

dan kita berikan fungsi tebakan awal, yaitu

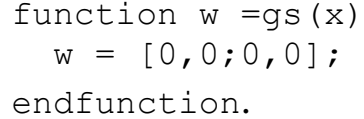

Kemudian untuk memperoleh solusi numerik MSB, diberikan dalam skrip SCILAB berikut

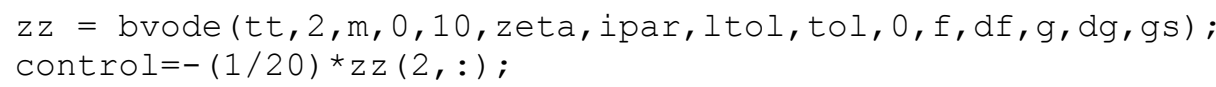

Solusi numerik yang diperoleh, ditampilkan oleh Scilab dengan memberikan skrip berikut ini

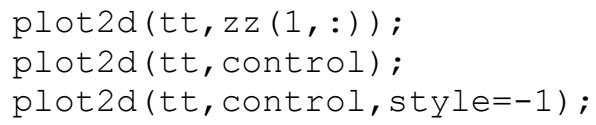

yang tampilan grafisnya diperlihatkan pada Gambar 3. 
A.D. GARNADI, E. SYAHRIL

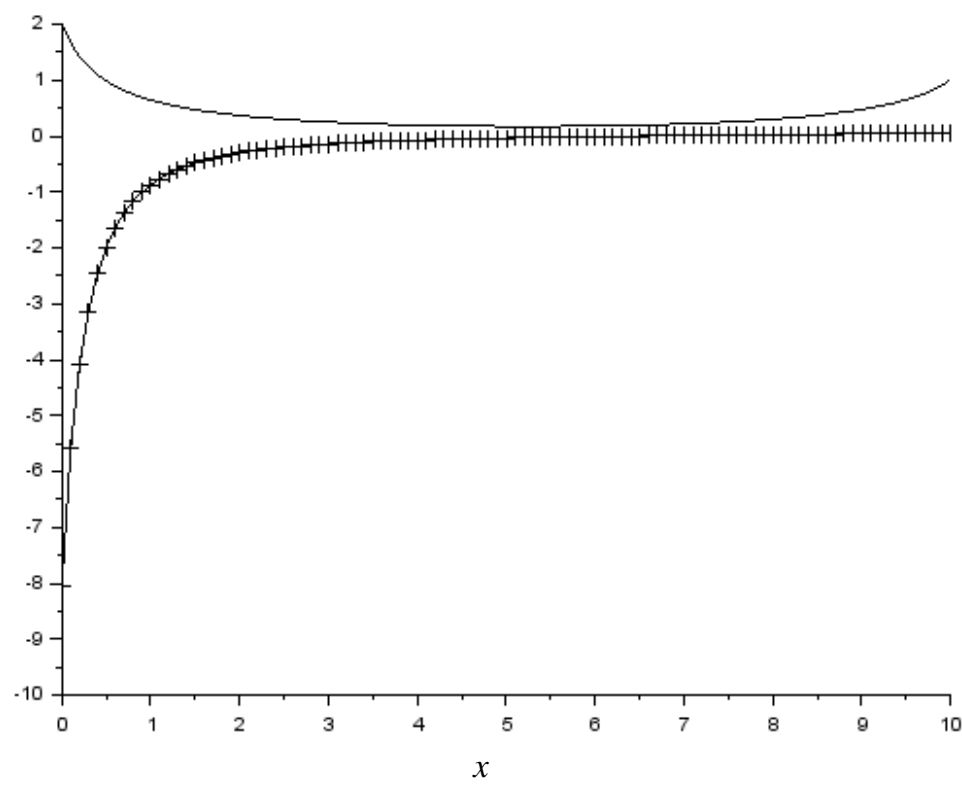

Gambar 3 Optimum $y$ (garis) dan kontrol $v$ (garis- $x$ ) untuk contoh 3.

\section{SIMPULAN}

Telah disampaikan bagaimana Masalah KO dapat diselesaikan sebagai masalah syarat batas, penggunaan MKO sering muncul sebagai model dari berbagai bidang ilmu. Karena untuk mendapatkan solusi analitik tidak selalu tersedia, metode numerik menjadi salah satu cara untuk memperoleh solusinya. Selain itu, dengan tersedianya rutin yang memudahkan pengguna untuk menyelesaikan MSB secara numerik, dimungkinkan melakukan simulasi secara berulang untuk menguji berbagai skenario pemodelan yang menggunakan MKO. Tulisan ini merupakan tutorial bagaiman menggunakan simulasi MSB dalam lingkungan problem solving environment SCILAB yang bersifat open source untuk menyelesaikan MKO. Perlu kiranya pengujian lebih lanjut atas rutin ini, antara lain menguji berbagai kasus di [7], yang memberikan serangkaian contoh MKO sebagai MSB.

\section{DAFTAR PUSTAKA}

[1] Ascher U, Christiansen J, Russel RD. 1981. Collocation Software for Boundary-Value ODEs.ACM Transactions on Mathematical Software. 7(2).

[2] Ascher U, Mattheij RM, Russel RD, Numerical Solution of Boundary Value Problem.New Jersey: Prentice-Hall, Englewood Cliffs.

[3] Campbell SL. Chancelier JP, Nikoukhah R. 2005.Modeling and Simulation in Scilab/Scicos. Springer.

[4] Higham DJ, Higham NJ. 2000.MATLABGuide. SIAM. 
JMA, VOL. yy, NO.1, JULY 2018, 1-xx

[5] Kierzenka J, Shampine L. 2001. A BVP solver on residual control and the Matlab PSE.ACM Transactions on Mathematical Software.27(3): 299-316.

[6] Moler CB. 2004.Numerical Computing with MATLAB. SIAM.

[7] S. N. Avvakumov and Yu.N. Kiselev, 2000, Boundary value problem for ordinary differential equations with applications to optimal control, Spectral and evolution problems \}, V10, pp 147--155

[8] Layar bantuan SCILAB untuk rutin bvode.

[9] Kaas R,Goovaerts M, Dhaene J, Denuit M. 2009.Credibility theory. Modern Actuarial Risk Theory: Using R.203-229.

[10] Young VR. 1997. Credibility using a loss function from spline theory. Scandinavian Actuarial Journal. 1997(2): 160-185. 